\title{
Predominance of a single major gene for resistance to Phakopsora pachyrhizi in a population of Glycine argyrea
}

\author{
A. M. Jarosz* $\ddagger$ and \\ J. J. Burdon†
}

\author{
* Department of Biology, Emory University, Atlanta, \\ Georgia, 30322, U.S.A. \\ $\dagger$ Division of Plant Industry, CSIRO, G.P.O. Box 1600, \\ Canberra City, ACT 2601, Australia.
}

Four phenotypic patterns of resistance and susceptibility to nine races of Phakopsora pachyrhizi were found among 104 lines derived from seeds collected from 49 plants of a Glycine argyrea population. Genetic analyses suggested that the three most common phenotypic patterns were determined by two alleles at a single locus. The fourth phenotypic pattern was represented by only a single line which was not analyzed genetically. These results contrast with those of a related species, $G$. canescens, where ten or more resistance genes were detected within each of two populations, and individuals often possessed two or more resistance genes. It is postulated that $G$. argyrea's relatively high rate of outcrossing and the apparent prevalence of forms of resistance which delay the development of the pathogen may have contributed to the small number of major resistance genes in this population.

\section{INTRODUCTION}

Pathogen infections have been postulated to be a major cause of frequency dependent selection within plant populations (see Burdon, 1987a, for review). Results from several broad scale surveys of host resistance have been consistent with the prediction that host populations should be polymorphic in regions where pathogen pressure is significant (Dinoor, 1970; Wahl et al., 1978; Segal et al., 1980; Burdon et al., 1983). However, genetic studies on the pattern of race specific resistance within populations indicate that the level of resistance polymorphism may differ from one hostpathogen combination to another and even between populations within a single host species. High levels of resistance to Phakopsora pachyrhizi were found in two populations of Glycine canescens (Burdon 1987b). Each population contained ten or more resistance genes. No individual in either population was susceptible to all nine races of $P$. pachyrhizi, and in most cases plants possessed two or three resistance genes. In Senecio vulgaris, most populations contained a considerable proportion of individuals which were fully susceptible to eight races of Erysiphe fischeri (Harry and Clarke, 1986). However, individuals possessing two or more resistance genes were common within the group

$\ddagger$ Present address: Department of Botany, Duke University, Durham, NC 27706, USA. of resistant plants (Harry and Clarke, 1986, 1987). In a third study which investigated resistance to local Synchytrium decipiens isolates in the plant Amphicarpaea bracteata, Parker (1988a) found that most plants were susceptible, and resistant plants carried only a single resistance gene. The reasons for the differences in resistance patterns among species and among populations within a species have not been extensively tested. Wahl (1970) and Dinoor (1970) have suggested that pathogen pressure is a primary factor in determining the level of resistance within populations. However, it seems likely that other factors, such as host life history and the mating systems of both the host and pathogen, would also have important effects on the patterning of resistance.

In this study we examine a population of $G$. argyrea Tind, with respect to the phenotypic patterning and genetic basis of major gene resistance to the soybean rust pathogen $P$. pachyrhizi Syd. The results are compared to those from a previous study which examined the resistance patterning in two populations of $G$. canescens. $G$. argyrea was chosen for comparison because it grows in a region which we judged to be more conducive to pathogen growth. We based this judgement on statements which indicated that soybean rust is a major disease of soybean along the east coast of Australia and not the interior (Kochman, 1977), and from herbarium records 
which indicate a greater prevalence of $P$. pachyrhizi along the east coast of Australia (Burdon and Lenné, 1989). Further, relative to $G$. canescens, $G$. argyrea displays much higher levels of outcrossing in chasmogamous flowers (Brown et al., 1986), and has a more restricted range (Tindale, 1984).

\section{MATERIALS AND METHODS}

G. argyrea seeds were collected by Grant (1986) from chasmogamous flowers at Rainbow Beach, Cooloola National Park, Queensland (25⒌' $153^{\circ} 06^{\prime} \mathrm{E}$ ) in December of 1984 . Seeds were nicked,

Table 1 Segregation patterns for resistance/susceptibility to Phakopsora pachyrhizi in $\mathrm{F}_{2}$ seedlings for lines derived from crosses involving a plant displaying Phenotype I or II and a fully susceptible plant

\begin{tabular}{|c|c|c|c|c|c|c|}
\hline \multirow{2}{*}{$\begin{array}{l}\text { Resistant } \\
\text { plant } \\
\text { number }\end{array}$} & \multirow{2}{*}{$\begin{array}{l}\text { Number } \\
\text { of } \\
\text { crosses* }\end{array}$} & \multirow{2}{*}{$\begin{array}{l}\text { Testing } \\
\text { races } \dagger\end{array}$} & \multirow{2}{*}{$\begin{array}{l}\text { Heterogeneity } \\
\chi^{2}\end{array}$} & \multicolumn{2}{|c|}{$\mathrm{F}_{2}$ individuals } & \multirow{2}{*}{$\begin{array}{l}\chi^{2} \text { for } \\
\text { 3:1 ratio }\end{array}$} \\
\hline & & & & $\mathbf{R}$ & $\mathbf{S}$ & \\
\hline \multicolumn{7}{|c|}{ Lines displaying a $3: 1$ ratio } \\
\hline $07011 \cdot 2$ & $2(1)$ & R8 & 0.04 & 321 & 91 & $1 \cdot 71$ \\
\hline 0702 2B & $2(2)$ & R2 & $0 \cdot 18$ & 452 & 171 & $1 \cdot 86$ \\
\hline $0704 \mathrm{~A}$ & $5(4)$ & R4, R7 & $2 \cdot 41$ & 725 & 272 & $2 \cdot 65$ \\
\hline $0705 \mathrm{~A}$ & $2(1)$ & R2, R6 & 0.42 & 328 & 94 & $1 \cdot 53$ \\
\hline $0706 \mathrm{~B}$ & $2(1)$ & $\mathbf{R 7}$ & 1.05 & 289 & 110 & $1 \cdot 27$ \\
\hline $07115 \mathrm{~A}$ & $3(3)$ & R8, R9 & $1 \cdot 77$ & 279 & 100 & $0 \cdot 32$ \\
\hline $07141 \cdot 2$ & $1(1)$ & $\mathrm{R} 3$ & - & 179 & 72 & $1 \cdot 63$ \\
\hline $07174 \mathrm{~A}$ & $1(1)$ & $\mathbf{R} 8$ & - & 79 & 39 & $3 \cdot 66$ \\
\hline $0719 \mathrm{~A}$ & $3(1)$ & R5 & $5 \cdot 13$ & 477 & 162 & $0 \cdot 03$ \\
\hline $07341 \mathrm{~A}$ & $2(1)$ & R7 & 0.05 & 177 & 42 & $3 \cdot 65$ \\
\hline $073510 \cdot 3$ & $2(1)$ & R6 & $0 \cdot 15$ & 142 & 61 & $2 \cdot 50$ \\
\hline $073510 \cdot 5$ & $1(1)$ & R1 & - & 137 & 53 & $0 \cdot 70$ \\
\hline $07374 \mathrm{~A}$ & $1(1)$ & R3 & - & 120 & 34 & 0.55 \\
\hline $07391 \mathrm{~A}$ & $2(2)$ & R9 & 0.01 & 145 & 49 & $<0 \cdot 01$ \\
\hline 07401.4 & $3(3)$ & R5, R8, R9 & 0.97 & 300 & 78 & $3 \cdot 61$ \\
\hline $07431 \mathrm{~A}$ & $2(1)$ & $\mathrm{R} 4, \mathrm{R} 8$ & 0.04 & 174 & 64 & $0 \cdot 36$ \\
\hline $07467 \cdot 1$ & $3(2)$ & R1, R9 & $1 \cdot 57$ & 242 & 101 & $3 \cdot 38$ \\
\hline $07473 \cdot 5$ & $1(1)$ & R8 & - & 58 & 28 & $2 \cdot 23$ \\
\hline $0749 \mathrm{~A}$ & $1(1)$ & R2 & - & 130 & 43 & $<0.01$ \\
\hline $0752 \mathrm{~A}$ & $2(2)$ & R2, R5 & $1 \cdot 54$ & 69 & 20 & $0 \cdot 18$ \\
\hline 07561 & 1(1) & R4 & - & 116 & 43 & $0 \cdot 25$ \\
\hline 0757 3R & $3(1)$ & R4, R5, R6 & $3 \cdot 83$ & 355 & 111 & $0 \cdot 29$ \\
\hline 07591 & $2(1)$ & R7, R8 & $1 \cdot 81$ & 237 & 96 & $2 \cdot 40$ \\
\hline 07621 & $5(3)$ & $\mathrm{R} 6$ & 1.44 & 546 & 180 & $0 \cdot 01$ \\
\hline 07702 & $3(2)$ & R5, R7, R8 & $3 \cdot 55$ & 469 & 145 & 0.56 \\
\hline $0771 \mathrm{~B}$ & $2(2)$ & R1 & $1 \cdot 06$ & 93 & 32 & $0 \cdot 01$ \\
\hline $07781 \mathrm{~A}$ & $2(2)$ & R1, R7 & $0 \cdot 24$ & 136 & 44 & $0 \cdot 01$ \\
\hline $07791 \mathrm{~A}$ & $2(1)$ & $\mathrm{R3}$ & 0.06 & 171 & 54 & $0 \cdot 07$ \\
\hline $07802 \cdot 2$ & $2(1)$ & R8 & $0 \cdot 17$ & 264 & 96 & 0.45 \\
\hline $07811 \mathrm{~A}$ & $2(1)$ & R3 & $0 \cdot 27$ & 133 & 45 & $<0.01$ \\
\hline $07822 \cdot 3$ & $2(2)$ & R6 & $0 \cdot 00$ & 144 & 48 & $0 \cdot 00$ \\
\hline 0799 B & $2(2)$ & R1, R2 & $0 \cdot 05$ & 111 & 35 & $0 \cdot 04$ \\
\hline \multicolumn{7}{|c|}{ Lines not displaying a } \\
\hline $07141 \cdot 5$ & $1(1)$ & R5 & - & 336 & 86 & $4 \cdot 56^{*}$ \\
\hline $07473 \cdot 4$ & $1(1)$ & R7 & - & 56 & 36 & $9 \cdot 06^{* *}$ \\
\hline $07481 \mathrm{~A}$ & $2(2) \S$ & & & & & \\
\hline C1-1 & & R3 & $47 \cdot 70^{* *}$ & 85 & 197 & - \\
\hline C2-1 & & R3 & $2 \cdot 60$ & 41 & 32 & $12 \cdot 83^{* *}$ \\
\hline $0763 \mathrm{~B}$ & $1(1)$ & R4 & - & 47 & 67 & $67 \cdot 56^{* *}$ \\
\hline 0769 B & $2(1)$ & R2, R7 & $1 \cdot 39$ & 562 & 145 & $7 \cdot 37^{* *}$ \\
\hline
\end{tabular}

* Number of $F_{1}$ hybrid plants used to produce seeds for $F_{2}$ testing. Values in parentheses are the number of different pollination represented by the $F_{1}$ plants.

$\dagger$ Designation of races follows that of Burdon and Speer (1984) and Burdon (1987b).

$\ddagger^{*}=$ significantly different from a $3: 1$ ratio at the 5 per cent level; ${ }^{* *}=$ significant at the 1 per cent level. All other values not significant at the 5 per cent level.

$\S$ The two crosses from this line could not be grouped due to significant heterogeneity among inoculation dates for the C1-1 cross. Heterogeneity $\chi^{2}$ values for the different crosses in this line test for heterogneity among inoculation dates. 
germinated and planted in $20 \mathrm{~cm}$ pots filled with $5: 3: 2$ sand, loam and perlite. In most cases more than one seedling was established from the seeds collected from a single field plant. These seedlings were grown as separate lines, but designated as belonging to the same family by shared 0700 numbers. Thus for example, lines 073510.3 and 0735 $10 \cdot 5$ (table 1) were lines derived from two separate seeds collected from one plant. The 0735 number designates a single plant in Cooloola National Park. Seedlings were grown to maturity and selfed seeds were collected from each plant and stored separately. These seeds were used to determine the resistance pattern of the original field collected seed.

\section{Pathogen isolates and inoculation procedures}

The resistance/susceptibility response to nine separate races of $P$. pachyrhizi was determined by inoculating a minimum of 15 seedlings for each host line by pathogen race combination. For six of the pathogen races, the virulence/avirulence pattern on a set of host differentials has previously been published (Burdon and Speer, 1984). Each of the remaining three races had a unique pattern of virulence/avirulence on the differential set (Burdon, unpublished). Pathogen culture maintenance and inoculation procedures were similar to those of Burdon (1987b). The only difference was that infection type ratings were assessed at 14-16 days after inoculation. Infection type ratings were similar to those of Burdon (1987b), and were based on the scale shown below:

\begin{tabular}{|c|c|}
\hline $\begin{array}{l}\text { Infection } \\
\text { Type }\end{array}$ & Symptoms \\
\hline ; & Necrotic flecks only, no sporulation \\
\hline 1 & $\begin{array}{l}\text { Minute uredia surrounded by relatively } \\
\text { large regions of necrotic tissue }\end{array}$ \\
\hline 2 & $\begin{array}{l}\text { Small uredia still associated with } \\
\text { hypersensitive areas of chlorotic or } \\
\text { necrotic tissue }\end{array}$ \\
\hline 3 & $\begin{array}{l}\text { Large profusely sporulating uredia with } \\
\text { little or no associated chlorotic or } \\
\text { necrotic tissue }\end{array}$ \\
\hline
\end{tabular}

Symptoms which overlapped two or more infection types were designated by a combination of both infection types. Similarly, intermediate infection types were designated as $1=, 1-, 1+$ and so forth. In this study resistant reactions ranged from (;) to $(; 1)$, while susceptible reactions were either $(2+, 3)$ or (3) reaction types.

\section{Genetic analysis of disease resistance}

The genetic analysis of resistance was investigated by crossing a subsample of the plants with one of two fully susceptible G. argyrea accessions, G1622 (CSIRO Division of Plant Industry Glycine sp. accession number) and 0702 2A. Attempts were made to generate at least one hybrid from each family. In most crosses the susceptible line was used as the female parent. The hybrid nature of the $F_{1}$ plants was verified from infection type response (resistance was assumed to be dominant) and by isozyme analysis on extracts from young leaves. Horizontal starch-gell electrophoresis was performed on crude leaf extracts (Burdon, 1987b). The gel buffer systems and enzyme assays were: (1) tris-citrate with lithium borate: aspartate aminotransferase (AAT; EC 2.6.1.1); (2) $5.0 \mathrm{mM}$ histidine, $p \mathrm{H} \mathrm{8.0:} \mathrm{glucosephosphate} \mathrm{isomerase}$ (GPI; EC 5.3.1.9), malate dehydrogenase (MDH; EC 1.1.1.37), and aconitate hydratase (ACO; EC 4.2.1.3).

Selfed seeds from confirmed $F_{1}$ hybrids were collected until there was sufficient seed for testing against one of the nine pathogen races. All of the $F_{2}$ progeny from a confirmed $F_{1}$ hybrid were tested against a single pathogen race. Inoculations and rating procedures were similar to the original selfed seedling tests.

In order to confirm the genetic basis of the observed $F_{2}$ segregation patterns, a number of $F_{2}$ seedlings were grown to maturity and $F_{3}$ seeds collected. All $\mathrm{F}_{3}$ seedlings derived from a single $F_{1}$ hydrid were inoculated with a single pathogen race. The $F_{3}$ segregation patterns were used to confirm the occurrence of both homozygous and heterozygous individuals in the resistant portion of the $F_{2}$ population, and to establish that susceptible plants bred true.

\section{RESULTS}

Only four phenotypic patterns of resistance/susceptibility were found among the $G$. argyrea from Cooloola National Park (fig. 1). Of the 104 lines tested, 103 displayed one of three main patterns: Lines displaying Pattern I were fully resistant to all nine pathogen races; Pattern II lines appeared to be segregating for resistance to all nine pathogen races; and Pattern III lines were susceptible to all nine pathogen races. For lines displaying Pattern II the number of resistant plants was always greater than the number of susceptible plants, with the exception of two lines from family 0763 . In these 


\begin{tabular}{|c|c|c|c|c|c|c|c|c|c|c|}
\hline \multirow{2}{*}{$\begin{array}{l}\text { Phenotypic } \\
\text { Pattern }\end{array}$} & \multicolumn{8}{|c|}{ Pathogen Races } & \multirow{2}{*}{$\begin{array}{l}\text { Number } \\
\text { of Families }\end{array}$} & \multirow{2}{*}{$\begin{array}{l}\text { Number } \\
\text { of Lines }\end{array}$} \\
\hline & R1 & R3 & R4 & R5 & R6 & R7 & R8 & $\mathrm{R} 9$ & & \\
\hline 1 & & & & & & & & & 24 & 43 \\
\hline 11 & & & & & & & & & 25 & 33 \\
\hline III & & & & & & & & & 20 & 27 \\
\hline IV & & & & & & & & & 1 & 1 \\
\hline
\end{tabular}

Figure 1 The four patterns of resistance/susceptibility to nine races of Phakopsora pachyrhizi in a population of Glycine argyrea. Stippled rectangles indicate a resistant reaction; open, susceptible; and split rectangles indicate that selfed seed from the original plant produced both resistant and susceptible seedlings.

two lines the number of susceptible plants was always greater than the number of resistant. The remaining phenotypic pattern (IV) was represented by the only line tested from family 0736 . Resistant reactions ranged from flecks (;) to flecks with light sporulation $(; 1=)$, with the most common reactions being flecks or flecks with very light sporulation $(; 1=)$. Flecks were usually red-brown to dark brown in colour.

In many instances there was variability in the phenotypic pattern among the different lines from a single family. Multiple lines from the same family were tested for 35 of the 49 families. Of these 35 families, 18 had lines which differed in their resistance pattern.

Thirty seven of the lines which displayed Phenotypic Patterns I or II were crossed with one of the susceptible lines (G1622 or 0702 2A). Thirty two of the lines had $\mathrm{F}_{2}$ segregation which indicated that resistance in the line was conferred by a single dominant allele (table 1). All the lines which displayed a $3: 1$ ratio had a $(;)$ to $(; 1=)$ resistant reaction with the fleck again being typically redbrown in colour. However, the resistant reaction of the $F_{2}$ often showed slightly more sporulation than that of the selfed seed from the resistant parent. This was most evident in lines $0706 \mathrm{~B}, 0575$ $3 R, 07591$, and $07802 \cdot 2$ where the selfed seedlings from the original parent always gave a fleck with no sporulation, while a small amount of sporulation was always evident on resistant $F_{2}$ seedlings. Given the similarity in the resistance reaction it seemed likely that all lines possessed the same resistance allele.

Of the five lines which did not fit a $3: 1$ ratio, two lines, 07141.5 and $0769 \mathrm{~B}$, had an excess of resistance plants. For the 07141.5 line the excess of resistant individuals was mainly due to the data from one inoculation date. If the data for this one date were excluded, the heterogeneity $\chi^{2}$ among dates dropped from 7.70 to 2.72 and the $F_{2}$ ratio for the remaining dates was 227 resistant to 68 susceptible. The $\chi^{2}$ for a fit to a $3: 1$ ratio was $0 \cdot 45$, indicating that this line probably has only a single dominant gene. In contrast the $0769 \mathrm{~B}$ line always had a consistent excess of resistant individuals for all inoculation dates, although the segregation data fit neither a $3: 1$ or $15: 1\left(\chi^{2}=245 \cdot 31\right)$ ratio.

The remaining three lines displayed an excess of susceptible individuals. Line 07473.4 had an $\mathrm{F}_{2}$ ratio which was consistent with a 9:7 ratio for resistance conferred by two dominant genes acting together $\left(\chi^{2}=0.80\right)$. Whether this truly indicates a two gene system is unclear since a related line from the same family (and from the same pod), $07473 \cdot 5$, had a ratio consistent with a $3: 1$ ratio. Although the 07473.5 line did have a slight excess of susceptible plants in the $F_{2}$ it did not fit a $9: 7$ ratio $\left(\chi^{2}=4 \cdot 37\right)$. Crosses from the $07481 \mathrm{~A}$ line were very perplexing, the different inoculation dates for cross C1-1 could not be grouped because they displayed a great deal of heterogeneity. The second cross involving this line, C2-1, did not fit a 3:1 ratio, but instead fit a 9:7 two gene ratio $\left(\chi^{2}<0 \cdot 01\right)$. Therefore, it is possible that some plants in the population were protected by a two gene resistance system. However, this possibility must be tempered by the behaviour of other crosses from the two families displaying the 9:7 ratios. Further, the resistance reaction of both lines displaying a 9:7 ratio was similar to that of lines displaying a $3: 1$ ratio.

The final line, $0763 \mathrm{~B}$, was the only line where the susceptible plants in the $F_{2}$ consistently outnumbered the resistant plants. However, the segregation ratio did not fit a $1: 3$ ratio $\left(\chi^{2}=16 \cdot 01\right)$. The cause of this unusual segregation ratio has not been determined. 
Table 2 Segregation patterns for resistance/susceptibility to Phakopsora pachyrhizi in $\mathrm{F}_{3}$ lines of five crosses involving plants which displayed Phenotype I or II

\begin{tabular}{|c|c|c|c|c|c|c|c|}
\hline \multirow{2}{*}{$\begin{array}{l}\text { Hybrid } \\
\text { number }\end{array}$} & \multirow{2}{*}{$\begin{array}{l}\mathrm{F}_{2} \\
\text { phenotype }\end{array}$} & \multirow[b]{2}{*}{$\begin{array}{l}\text { Number of } \\
\text { families }\end{array}$} & \multirow[b]{2}{*}{$\begin{array}{l}\text { Testing } \\
\text { race* }\end{array}$} & \multirow[b]{2}{*}{$\begin{array}{l}\text { Heterogeneity } \\
\chi^{2}\end{array}$} & \multicolumn{2}{|c|}{$F_{3}$ phenotype } & \multirow{2}{*}{$\begin{array}{l}\chi^{2} \text { for } \\
3: 1 \text { ratio }\end{array}$} \\
\hline & & & & & $\mathrm{R}$ & $S$ & \\
\hline \multirow[t]{2}{*}{0704 A C3-1 } & $\mathrm{R}$ & 6 & $\mathrm{R} 7$ & - & 241 & 0 & - \\
\hline & $\mathrm{R}$ & 6 & R7 & $7 \cdot 30^{(5)} \dagger$ & 204 & 79 & $1 \cdot 28$ \\
\hline \multirow[t]{3}{*}{0719 A C1-3 } & $\mathrm{R}$ & 6 & R5 & - & 301 & 0 & - \\
\hline & $\mathrm{R}$ & 2 & R5 & $0 \cdot 32^{(1)}$ & 76 & 27 & 0.08 \\
\hline & $S$ & 2 & R5 & - & 0 & 92 & - \\
\hline \multirow[t]{2}{*}{0757 3R C1-2 } & $\mathrm{R}$ & 4 & R4 & $2 \cdot 30^{(3)}$ & 140 & 34 & 3.77 \\
\hline & S & 2 & $\mathrm{R} 4$ & - & 0 & 95 & - \\
\hline \multirow[t]{2}{*}{$07702 \mathrm{C} 1-1$} & $\mathrm{R}$ & 2 & R6 & - & 100 & 0 & - \\
\hline & $\mathrm{R}$ & 12 & R6 & $4 \cdot 42^{(11)}$ & 526 & 173 & 0.02 \\
\hline \multirow[t]{3}{*}{$07802 \cdot 2 \mathrm{C} 1-1$} & $\mathrm{R}$ & 2 & R3 & - & 104 & 0 & - \\
\hline & $\mathrm{R}$ & 5 & R3 & $4 \cdot 10^{(4)}$ & 190 & 67 & $0 \cdot 16$ \\
\hline & $\mathrm{S}$ & 1 & R3 & - & 0 & 45 & - \\
\hline
\end{tabular}

* Designation of races follows that of Burdon and Speer (1984) and Burdon (1987b).

$\dagger$ Number in parentheses indicates the number of degrees of freedom.

We also point out that the non-3:1 ratios were not due to the behaviour of any single pathogen race (table 1 ). Five separate testing races were found among the host-pathogen combinations which gave non $-3: 1$ ratios. Each of these races was used to test other host lines which displayed $3: 1$ ratios. It was often the case that lines displaying a 3:1 ratio were inoculated simultaneously with lines which did not.

In order to confirm that susceptible plants were true breeding, crosses were made among seven lines which displayed Pattern III. The $F_{2}$ progeny from all such crosses were susceptible.

The presence of a single dominant allele conferring resistance was confirmed by the $\mathrm{F}_{3}$ segregation patterns of five crosses which displayed a $3: 1$ ratio in the $\mathrm{F}_{2}$ (table 2). In four of the five crosses both homozygous and heterozygous resistant individuals were detected. The $\mathrm{F}_{3}$ segregation patterns of the heterozygous class from all five crosses fit a 3:1 ratio. Susceptible $F_{2}$ individuals from three crosses were also grown to produce $\mathrm{F}_{3}$ seedlings, all of which were fully susceptible.

\section{DISCUSSION}

Phenotypic and genetic patterns of resistance in $\mathrm{G}$. argyrea

Two lines of evidence indicated that resistance to $P$. pachyrhizi in the $G$. argyrea population found in the Cooloola National Park was dominated by a single allele. First, was the very high frequency of lines which displayed phenotypic patterns I, II, or III (fig. 1). These patterns would be expected when the original progenitor of the line was, homozygous for the allele (Pattern I), heterozygous for the allele (Pattern II), or where the allele was absent (Pattern III). Second, the $F_{2}$ segregation pattern of 32 of the 37 crosses which involved lines which displayed Patterns I or II indicated that resistance was in fact conferred by a single dominant allele (table 1). This was further confirmed by the $F_{3}$ segregation data were again consistent with the hypothesis that most Pattern I and II lines carried a single dominant resistance allele. The similarity in the resistance reaction of all lines, while not being conclusive, would further indicate that these lines possessed the same resistance allele.

Five lines did not have a $3: 1$ segregation ratio among the $F_{2}$ seedlings (table 1). However, it is unclear whether these lines in fact possessed unique resistance alleles. The phenotypic pattern of resistance/susceptibility and the resistance reaction in these lines were similar to that of lines which displayed a $3: 1$ ratio in the $F_{2}$. Burdon (1987b) found that $G$. canescens plants which possessed different resistance alleles most often differed in either phenotypic pattern or the expression of the resistance reaction. Further evidence against these lines possessing unique resistance alleles came from the behaviour of other crosses in the same family (0747 and 0763), or the fact that the $F_{2}$ segregation ratio did not fit any simple Mendelian pattern of inheritance (0714 1.5, 
$0763 \mathrm{~B}$ and $0769 \mathrm{~B})$. The only line which definitely possessed a unique form of resistance was 0736 which displayed pattern IV (fig. 1). Unfortunately it was not possible to genetically test this line.

\section{Comparison with the phenotypic and genetic patterns in other host species}

The relatively small number of phenotypic patterns for resistance/susceptibility in G. argyrea contrasts with the marked diversity found in other wild systems. Studies of the resistance patterns in wild cereal populations from the Middle East have found populations to be composed of complex mixtures of individuals with different phenotypic patterns (Wahl et al., 1978; Segal et al., 1980; Moseman et al., 1983, 1984). Dinoor (1977) found that resistance patterns to crown rust, Puccinia coronata, in wild Avena spp. populations were highly variable. Similarly, high levels of resistance variability were found in Avena populations from Australia (Burdon et al., 1983).

The most directly comparable work comes from two populations of $G$. canescens which were tested for their resistance patterns using the same nine pathogen races used in this study (Burdon, 1987b). Both populations were highly variable. In one population 12 separate phenotypes were detected in a sample of 14 plants, while in the second 11 phenotypes were found in a sample of 22 plants. In contrast, we found only four phenotypes in a sample of 104 lines from 49 families. Further, no plant in either $G$. canescens population was susceptible to all nine pathogen races, while 28 per cent of the $G$. argyrea lines were susceptible. Genetic differences mirrored the phenotype differences. The majority of $G$. argyrea plants contained only one resistance allele, while most $G$. canescens plants had two or even three separate resistance genes. At the population level, each $G$. canescens population contained ten or more separate resistance alleles, while the $G$. argyrea population most likely contained only two distinct resistance alleles.

The small number of resistance alleles in $G$. argyrea was unexpected since the species inhabits an area thought to be more conducive to $P$. pachyrhizi than either $G$. canescens population. The lack of genes which confer outright resistance may reflect a greater dependence on forms of resistance which simply delay pathogen development. The latent period, which is an important component of pathogen development, was between one and three days longer on $G$. argyrea than on $G$. canescens (Jarosz and Burdon, unpublished). Delaying pathogen development has been postulated to be an important component of the resistance arsenal of wild hosts, however, only one study has documented its existence within a natural hostpathogen system (Segal et al., 1987). To a large extent this reflects the difficulty in evaluating this form of resistance and not its actual occurrence.

\section{Mating system and response to pathogen pressure}

Parker (1988b) reported an extreme case of linkage disequilibrium in $A$. bracteata where resistance to $S$. decipiens was associated with a specific multilocus isozyme biotype. He concluded that this was the result of the strongly inbred nature of $A$. bracteata, and implied that selection favouring resistance would influence the evolution of neutral and near-neutral characters. However, one other consequence of linkage disequilibrium due to inbreeding is that the fate of a resistance gene is tied to the rest of the genome, and complex selective forces operate on individual resistance genes. Therefore, inbred species may accumulate resistance genes with time; as new favoured resistance genes increase in the population many of the preexisting resistance genes, which may be largely ineffective against the pathogen races currently attacking the population, may also increase due to hitchhiking. This may explain the common occurrence of individuals with multiple resistance genes in studies which have examined highly inbred species (Dinoor, 1977; Burdon, 1987b; Harry and Clarke, 1987).

In species with some degree of outbreeding, linkage disequilibrium will be reduced and pathogen pressure will act on individual genes. Under these conditions only effective resistance genes will increase in the population, and ineffective resistance genes may actually decrease in frequency if there is a cost associated with their presence in the genome. This may help to explain the pattern in $G$. argyrea where outcrossing in chasmogamous flowers has been estimated to be 38 per cent (Brown et al., 1986). Multilocus isozyme phenotypes were known for 39 of the lines used in this study (A. H. D. Brown, unpublished). The frequency of the resistance allele in this sample of 39 plants was $0 \cdot 564$. Four isozyme loci, AAT 1A, AAT 2, Gpi 2A, Gpi 2B and Mdh 3 (designations of Brown et al., 1986, and Brown unpublished) were highly polymorphic, with the frequency of the most common allele at each locus being $0.551,0.566,0.769,0.782$ and 0.808 , respectively. Unlike $A$. bracteata where resistance was associated with a single multilocus genotype, in 
G. argyrea there were fourteen separate multilocus isozyme genotypes among the fifteen plants homozygous for resistance; fourteen genotypes among the fourteen plants heterozygous for resistance, and eight genotypes among the ten plants that were susceptible to all nine races. The small number of resistance genes in $G$. argyrea may simply reflect selection which has favoured one highly effective resistance gene which has been able to largely supplant other race specific resistance genes within this population.

Acknowledgements We thank Dr A. H. D. Brown for providing unpublished isozyme data on the $G$. argyrea lines, and for his comments on earlier drafts of this paper. We also thank Miss Thea Huber for her excellent technical help.

\section{REFERENCES}

BROWN, A. H. D., GRANT, J. E. AND PULLEN, R. 1986. Outcrossing and paternity in Glycine argyrea by paired fruit analysis. Biol. J. Linn. Soc., 29, 283-294.

BUrdon, J. J. 1987a. Diseases and Plant Population Biology. Cambridge University Press.

BURDON, J. J. 1987b. Phenotypic and genetic patterns of resistance to the pathogen Phakopsora pachyrhizi in populations of Glycine canescens. Oecologia, 73, 257-267.

BURDON, J. J. AND LENNÉ, J. M. 1989. The Phakopsora pachyrhizi-Kennedia rubicanda host-pathogen association and its relation to leaf rust of Glycine spp. Australian Journal of Agricultural Research, 40, 265-272,

BURDON, J. J., OATES, J. D. AND MARSHALL, D. R. 1983. Interactions between Avena and Puccinia species. I. The wild hosts: Avena barbata ex Link, A. fatua L. and $A$. ludoviciana Durieu. Journal of Applied Ecology, 20, 571584.

BURDON, J. J. AND SPEER, S. S. 1984. A set of differential hosts for the identification of pathotypes of Phakopsora pachyrhizi Syd. Euphytica, 33, 891-896.

DINOOR, A. 1970. Sources of oat crown rust resistance in hexaploid and tetraploid wild oats in Israel. Canadian Journal of Botany, 48, 153-161.
DINOOR, A. 1977. Oat crown rust in Israel. Annals of the New York Academy of Sciences, 287, 357-366.

GRANT, J. E. 1986. Interspecific Hybridization in the Genus Glycine. Ph.D. Thesis, Australian National University.

HARRY, I. B. AND CLARKE, D. D. 1986. Race-specific resistance in groundsel (Senecio vulgaris) to the powdery mildew Erysiphe fischeri. New Phytologist, 103, 167-175.

HARRY, I. B. AND CLARKE, D. D. 1987. The genetics of racespecific resistance in groundsel (Senecio vulgaris L. ) to the powdery mildew fungus Erysiphe fischeri Blumer. New Phytologist, 107, 715-723.

Kochman, J. R. 1977. Soybean rust in Australia. In Ford, R. E. and Sinclair, J. B. (eds) Rust of Soybeans-the Problems and Research Needs, INTSOY Series No. 12, University of Illinois, Urbana, USA.

MOSEMAN, J. G., NEVO, E. AND EL MORSHIDY, M. A. 1984. Resistance in Triticum dicoccoides to infection with Erysiphe graminis tritici. Euphytica, 33, 31-47.

MOSEMAN, J. G., NEVO, E. AND ZOHARY, D. 1983. Resistance of Hordeum spontaneum collected in Israel to infection with Erysiphe graminis hordei. Crop Science, 23, 1115-1119.

PARKER, M. A. 1988a. Polymorphism for disease resistance in the annual legume Amphicarpaea bracteata. Heredity, 60, $27-31$

PARKER, M. A. 1988 b. Disequilibrium between disease-resistance variants and allozyme loci in an annual legume. Evolution, 42, 239-247.

SEGAL, A., DORR, K. H., FISCHBECK, G., ZOHARY, D. AND WAHL, I. 1987. Genotypic composition and mildew resistance in a natural population of wild barley, Hordeum spontaneum. Plant Breeding, 99, 118-127.

SEGAL, A., MANISTERSKI, J., FISCHBECK, G. AND WAHL, I. 1980. How plant populations defend themselves in natural ecosystems. In Horsfall, J. G. and Cowling, E. B. (eds) Plant Disease: An Advanced Treatise, vol. 5, Academic Press, pp. 75-102.

TINDALE, M. D. 1984. Two new eastern Australian species of Glycine Willd. (Fabaceae). Brunonia, 7, 207-213.

WAHL, I. 1970. Prevalence and geographic distribution of resistance to crown rust in Avena sterilis. Phytopathology, 60, 746-749.

WAHL, I., ESHED, N., SEGAL, A. AND SOBEL, Z. 1978. Significance of wild relatives of small grains and other wild grasses in cereal powdery mildews. In Spencer, D. M. (ed.) The Powdery Mildews, Academic Press, pp. 83-100. 